\title{
The children of God and the children of darkness on the day of the Lord
}

\author{
Martin L. Nelwan \\ Nelwan Institution for Human Resource Development \\ Jl. A. Yani No. 24, Palu 94111, Indonesia \\ E-mail: mlnelwan2@gmail.com
}

\begin{abstract}
The children of God are Jesus Christ's followers and are occupants of heaven. The children of darkness are those who admit that Satan or the false prophet as their lord. They have no love and have antagonism. They live in flesh. Children of darkness are occupants of hell. The devils have always tried to tempt the children of God convert to their faith. Even Satan has tempt Jesus Christ to become his followers but failed. Consequently, he tried to kill Christ on the cross and again failed. Mathematically, Christ is higher than Satan is; the false prophet is, not vice versa. It is a scholarly proof. It shows that the children of God are higher than Satan is. Children of God should hold Christ in daily life to enter the kingdom of heaven on the last day. On that day, Jesus Christ will take the children of God into heaven. On the other hand, he will put Satan, his angels, the false prophet, false prophets, false teachers, and their followers will enter hell. It is the forever punishment.
\end{abstract}

\section{Introduction}

The day of the Lord is the time when Jesus Christ comes to this world for the second time. Christ will not come as a baby, born by a mother, then grows up as a man, as around two thousand years ago. He shall not take the process as he came for the first time to this globe. He shall come as he went to the kingdom of God around two thousand years ago. It can be meant that he shall be as an "adult man" when he comes to this world for the second time. According to the gospel, no man knows the day when Jesus Christ shall come, according to the gospel. Only God or Christ knows that time. But of that day and that hour knoweth no man, no, not the angels which are in heaven, neither the Son, but the Father (Mark $13: 32$ ).

On the day of the Lord, the spiritual man, the children of God shall be caught up in the clouds to meet the Lord in the air. The natural man; the children of Satan shall be punished forever. Satan, his angles and children, all of them are not part of the kingdom of God. They do not live in the Spirit. They have antagonistic behavior and love murder and persecution. Scholarly evidences show that these traits are inheritance trait. The only way to clean those traits is life in the Spirit. Christ showed directly that way to humans around two thousand years ago. There is no other way!

This paper attempts to address the following question: Are there evidences in the Bible that Christ, the Savior, will come to this world for the second time? Are there Satan, his angels, and the false prophet? Who are they? What they will be punished on the Day of the Lord? What is the mathematical symbol for the kingdom of God and the kingdom of darkness?

\section{Methodology}


The author searched the Bible to get verses for the Lord's Day and the sons of God and angels. Searches also included verses for Satan, his angels and the false prophet with his followers. References written by the author and other relevant publications were also included.

The scriptures are suitable with science. Early Christian has used ancient statistics or mathematics to resolve their daily problems. When selecting substitute Jude Iscariot, The disciples used a lot method. There were two equally good perspective apostles to replace Iscariot: Mathias and Justus. To select one, they decided it by lot and they got Mathias as substitute Jude Iscariot [Act 1:26]. "One day is with the Lord as a thousand years" [II Petr. 3:8]. It is mathematics. Lots are base of statistics. Biology and genetics use statistics methods to analyze research results. This study uses health, genetics, and mathematics for explaining the truth in Christianity.

\section{Results and Discussion}

The Lord will come to the earth for the second time, and will separate people who believe in Christ from people who do not believe in Christ. People who do not believe in Christ will go through forever punishment [Rev. 20:9, 10]]. People who exist and rise in Christ will experience change as his glorious body [Phil. 3:21], and shall be up in the clouds to meet the Lord in the air [1 Thess. 4:17], and then enter the heaven.

Humans who live in Christ are humans who hope life forever from Christ until the end of their life on the globe. The criminal who was crucified along with Jesus Christ around two thousand years ago saw paradise on that day. He did not need to wait until the end of the globe. Christ promised him for life forever in paradise [Luke 23:43]. It suggests that a criminal can enter the kingdom of God if he/she believes to Christ. Anyone who believe in Christ will not dead forever [John 3:36, John 11:26], and will enter the kingdom of God. The Lord's pray can help us to enter the kingdom. Anyone who holds to this pray will enter the kingdom. Be holly, forgive other sins, and do not live in the flesh [Gal. 5:22, 23, 24, 25, 26]. It is important things to enter the kingdom of God. In addition, this Lord's pray could protect anyone from sickness. "Give us this day our daily bread" [Matt. 6:11]. It suggests that we cannot pray for daily excessive bread. It could be dangerous for us. Anyone who eats daily with excessive pig meat could be punished. He/she may have high cholesterol and may cause hot attract. It is a simple example. Thousands of years ago, humans had not yet known to get information for cholesterol condition in their body. Thus, it was a good idea not to eat the pig fat. It would limit cholesterol within the body. Today, with the development of knowledge, humans may arrange their feeding every day. By that way, humans can reduce to pig meat. Thus, it will control cholesterol in the body, and can prevent hot attack. Holds the Lord's pray and the kingdom of God is for us!

"Now the brother shall betray the brother to death, and the father the son; and the children shall rise up against their parents, and shall cause them to be put to death. And ye shall be hated of all men for my name's sake: but he that shall endure unto the end, the same shall be saved" (Mark 13:12, 13). The children of Satan with their murderer and persecution traits; that are inherited from Adam and Eve and Cain, are doing their antichrists behaviors. The children of darkness have antagonistic behavior. It is an antisocial behavior. Nelwan suggested that antagonistic 
behavior comes from permanent changes in the $M A O A$ gene. It is the $M A O A-L$ allele. Indeed, several genes relate to antagonistic behavior. However, the $M A O A-L$ allele is the only gene that can be explained for antagonism trait at present. Antagonistic behavior with the MAOA-L allele can reach up to $41 \%$ of the population [1]. This behavior can arise in either family or community. Therefore, anyone among Jesus Christ disciples, who has the MAOA-L allele, could be an antichrist. Jude Iscariot was an apostle of Jesus Christ. He sold Jesus Christ to priest Caiaphas [Matt. 27:3]. Jude Iscariot was a liar, a murderer, and his father is Satan. Satan is a liar and a murderer from the beginning [John 8:44].

In genetics, antagonistic behavior is a behavior disorder inherited according to X-linked inheritance pattern. Parents with carrier female and normal male may have $50 \%$ carrier female children and 50\% normal female children. In addition, they may have male children around 50\% normal and 50\% antagonistic behavior. Parents with normal female and antagonistic behavior male may have all carrier female children and all antagonistic behavior male children. Parents with carrier female and antagonistic behavior male may have four behaviors. These include $25 \%$ antagonistic behavior female, $25 \%$ carrier female, $25 \%$ normal male, and $25 \%$ antagonistic behavior male. It shows that antagonistic behavior is an inheritance behavior from one generation to the next. It strengthens that "sin" behavior is an inheritance sin. Female is a carrier for antagonistic behavior. It suggests that antagonistic behavior is an inheritance of behavior from human's ancestor. People with antagonistic behavior can mean that they love to kill and hate.

Jesus Christ is from above not from beneath. His hands are free of human bloods. He does not have aggression traits such as Moses and David. For this, Moses stated to his followers that God would raise up a Prophet for them (Deut. 18:15) and he is esteeming Christ (Heb. 11:26). Christ came to this world around two thousand years ago to make perfect the Torah not to destroy it. If Moses led the Israeli with aggression traits facing their enemies, Jesus Christ does not have those traits. David therefore himself calleth him Lord; and whence is he then his son? And the common people heard him gladly (Mark 12 : 37). Both Moses and David honor him. Jesus Christ is the Spirit not the flesh. Christ is free of antagonistic behavior. Therefore, the children of God should not have antagonistic behavior, and should have love to human being as thyself [Matt. 22:39]. Jesus Christ is the Savior of humans from sins.

In Revelation, there are angels in heaven. At least nine angels are in the heaven. Michael, Gabriel, and seven other angels are described in Revelation. It shows that in kingdom of God exists God or Christ, angels, apostles, and sons of God (Table 1). Children of God maybe include other creatures beyond humans and angels [Rom. 8:22, 39; Mark 16:15]. The kingdom of God is the same as this mathematical formula $-\sim \mathrm{X} \leq \sim, \mathrm{X}=\mathrm{Y}$. Jesus Christ as first child of God includes that formula. He was from the heaven around two thousand years ago. He came to the earth to preach the gospel. Christ is already life in heaven forever [2]. His opponents, Satan and the false prophet, will not enter the kingdom. Both of them have already died forever. Jesus Christ will raise the false prophet and will send him to hell.

Before the day of the Lord, The false prophet and antichrists shall fight Jesus Christ teachings. "And then if any man shall say to you, Lo, here is Christ; or, lo, he is there; believe him not: For false Christ and false prophets shall rise, and shall shew signs and wonders, to seduce, if it were 
possible, even the elect. But take ye heed: behold, I have foretold you all things" (Mark $13: 21$, $22,23)$. Satan could bring and explain to the false prophet regarding heaven, He indeed knows about the heaven, so he could convince the children of darkness, including the false prophet, that he is God. Therefore, the false could explain to his followers regarding the heaven, so that they believe to Satan as God. Satan was in heaven before fighting God, so he knows about paradise. Do not believe to Satan and the false and you will enter the paradise! If Satan has successful entrapped you to make a sin, do not believe him.

God will forgive you whatever your sins! David made sin. He took Uriah's wife by killing Uriah in the forefront of the hottest battle [II Sam. 11:15, 21]. David really repented his sin and back to God. God accepted his repentance. Saul made sin. He transgressed God commandment and did not repent to God [I Sam. 13:13, I Sam. 15:23]. Saul sought a woman that have a familiar spirit to find Samuel [I Sam. 28:7], whereas Samuel has already passed away [I Sam. 28:3, 11]. He added his sins in the front of God. God could not forgive his sins. Both David and Saul were kings of Israel. "Though your sins be as scarlet, they shall be as white as snow [Isa. 1:18]. Jude Iscariot sold Jesus Christ with 30 pieces of silver to priests [Matt. 27:3]. He collaborated with them and then suicide [Matt. 27:5]]. Iscariot was an apostle of Jesus Christ. It seems that there will be many people as Iscariot and Saul. Many people will take their style and they shall cause the way of truth shall evil spoken of [II Pet. 2:2]. A son of darkness may come to a son of God to buffet her/him as Paul's experience [II Cor. 12:7]. To face this, the children of God should pleasure in infirmities, in reproaches, in necessities, in persecutions, in distresses [II Cor. 12:10]. "Blessed are the pure in heart: for they shall see God" [Matt. 5:8]. The children of darkness will sell children of God for moneys and other materials such as gold, money, and silver. These people work together with the false prophet, false prophets, false teachers, or children of darkness for their personal interests. People as Iscariot, Saul, and the false prophet are not belonging to kingdom of God. They are belonging to kingdom of darkness.

Table 1. The heaven [1] and hell [2]

\begin{tabular}{cc}
\hline [1] & {$[2]$} \\
\hline God \& Christ & Satan \\
Angels: & Angels: \\
Michael & "Michael" \\
Gabriel & "Gabriel" \\
A & A' $^{\prime}$ \\
B & B' $^{\prime}$ \\
C & C' $^{\prime}$ \\
D & D' $^{\prime}$ \\
E & E' $^{\prime}$ \\
F & F' $^{\prime}$ \\
G & G' $^{\prime}$ \\
Apostles & False Prophet \\
Children of God & Children of dark. \\
\hline
\end{tabular}


Satan had tried to bring Jesus Christ to become his follower but failed. He brought Christ upon the Mount, so it is the highest temptation a man has experienced. Jesus rejected to become Satan follower [Matt. 4:1-11]. Do not be afraid to Satan, the false prophet, false teachers, and their followers. "Submit yourselves therefore to God. Resist the devil, and he will flee from you" [James 4:7]. Believe in Christ and God shall bring you into heaven [Matt. 5:3 and James 4:10].

The false prophet or the antichrists, have antagonistic behavior. They are murderers and rappers. However, they stated that they are free of sins. They love money. Money is root of all evil [I Tim. 6:10]. They will seek the children of God to do their hates and angers towards the children of God. The false prophet and antichrists will not enter the kingdom of God. They will be punished on the day of the Lord. Christ and his disciples have shown the advent of the false prophet and false teachers around two thousand years ago. The antichrists behaviors will be ended on the day of the Lord as the Lord's promise to the children of God. Even, John in Revelation has seen that Satan and his angels, the false prophet and his followers (Table 1) have been punished forever in hell [Rev. 20:9, 10]]. All of them have mathematical symbol as $-\sim \leq X$ $<\sim, \mathrm{X}=\mathrm{Y}$. Satan was thrown from heaven to earth and cannot go back to heaven $\mathrm{X}<\sim$. Satan's angels, the false prophet and his followers are the children of darkness. All of them have the symbol $\sim \leq \mathrm{X}<\sim, \mathrm{X}=\mathrm{Y}$. They cannot enter the paradise.

Satan, the false prophet, and false teachers are blasphemers of God. The false prophet blasphemes God, Christ, that he is higher than Christ is [Rev.13:6]. He blasphemes Holy Ghost, therefore, shall never be forgiven [Mark 3:29]. The false prophet and his followers blaspheme Christ, saints [Rev. 13:6, I Pet. 2:1], and children of God [I Pet. 2:1]. Therefore, their place is hell [Rev. 20:9-10]. The false prophet has number: Six hundred threescore and six [Rev. 13:18]. He believes the devil as his God, says he is Christ, and shall deceive many [Mark 13:6]. He has the power to overcome the saints [Rev. 13:7]. Many will believe that the false is Christ, and will believe that Satan is God. Jesus Christ stated that false Christ would come to the earth and deceive many [Mark 13:6]. However, as the children of God, we know the truth Christ and the false one by these mathematical symbols: $-\sim \leq \mathrm{X} \leq \sim$ and $-\sim \leq \mathrm{X}<\sim$ in which $\mathrm{X}=\mathrm{Y}$. The $-\sim \leq \mathrm{X}$ $\leq \sim$ means that Christ comes from heaven and has already in heaven. The $-\sim \leq X<\sim$ states himself from heaven but he cannot enter the kingdom of God. God has punished him going to hell. Satan, his angels, the false prophet and his followers, and false teachers will go to hell [Rev. 20:9, 10]. The $-\sim \leq \mathrm{X} \leq \sim, \mathrm{X}=\mathrm{Y}$ is one of the scholarly proofs that Christ and the children of Gods are the truth.

"Repent yet: the kingdom of heaven is at hand" [Matt. 3:2]. Anyone who believes in Christ will be alive forever [John 3:16]. Jesus Christ is in heaven to prepare a place for each son of God [John. 14:2]. Christ for the second time on the day of the Lord takes and brings the children of God to heaven [John 14:3; I Thess. 4:16-17]. The Lord will come to the earth soon [Rev. 22:20]. Therefore, repent yet and shall enter the kingdom of heaven. Under no circumstances, hold on Christ and shall enter the kingdom of God. Job Suffered with disease and various distresses. He held on God and life in happiness when he was an old man [Job 42:10, 17]. Elisha died as his sickness [II Kings 13:14]. It means that he experienced distress, maybe pain, before dying. He did not leave God and hold forever to God. His bones revived a dead man [Kings 13:21]. It shows that Elisha is a truth prophet and a son of God. Both Elisha and Job are the children of God. They shall inhibit the kingdom of heaven. 


\section{Conclusions}

The children of God are people who believe on Jesus Christ as Christ, Lord. Anyone, who dies as sickness or distress and hold on Christ, belongs to children of God. Children of darkness are people who blaspheme Jesus Christ as Christ, and blaspheme the saints and the children of God who believes on Jesus Christ as Christ. Christ is the same as God. God, Christ, angels, and the children of God have place in heaven. Satan, his angels, the false prophet, and their followers have place in hell. They love to persecute, disapprove, or kill people who do not agree on their opinions. Anyone who acknowledges that he/she is a son of God but not life in spirit belongs to children of darkness. The mathematical symbol of God, Christ, his angels, and children of God is $-\sim \leq \mathrm{X} \leq \sim, \mathrm{X}=\mathrm{Y}$. The mathematical symbol of Satan, his angels, the false prophet, their followers, false prophets, false teachers and the flesh is $-\sim \leq \mathrm{X}<\sim$ and $\mathrm{X}=\mathrm{Y}$.

\section{References}

1. Nelwan ML .Moderate the MAOA-L Allele Expression with CRISPR/Cas9 System. Preprints 2018, 2018040275. DOI:10.20944.preprints201804.0275.v3.

2. Nelwan ML. The Spiritual Journey of Jesus Christ. OSF Preprints 2018. DOI:10.3129/osf.io/6ke53. 